\title{
Openness and the Effects of Monetary Policy on the Exchange Rates: An Empirical Analysis
}

\author{
Nihat Işık \\ Selçuk University, Turkey \\ Mustafa Acar \\ Kýrýkkale University, Turkey \\ H. Bayram Işık \\ Atatürk University, Turkey
}

\begin{abstract}
This paper examines whether the effects of monetary policy on the exchange rates depend on the degree of openness of an economy. Theoretically, it can be shown that the effect of openness on the ability of money to influence the exchange rate is ambiguous. In light of this, the purpose of this study is to investigate how the relationship between monetary policy and exchange rate is affected by openness, hence shedding some light on the theoretical ambiguity. Using annual data for a panel of 41 countries for the period 1988-2000, the paper's empirical results indicate that the effects of monetary policy on the exchange rates are negatively affected by economy's openness. It seems that the more open the economy, the smaller is the depreciation effects of a given increase in the money growth rate. More interestingly, contrary to conventional expectations, monetary expansions in developed countries do not seem to result in depreciation of the domestic currency.
\end{abstract}

*Corresponding address: Kýrýkkale Üniversitesi, ÝÝBF, Ýktisat Bölümü, Kýrýkkale, Turkey, Tel: 90-533632 4766, Fax: 90-312-230 8003, Email: acarm@ superonline.com (C)2005-Center for International Economics, Sejong Institution, All Rights Reserved. 


\section{- JEL classification codes: E52, F41}

- Keywords: Openness, monetary policy, exchange rate

\section{Introduction}

In economic literature it is widely accepted that monetary policies are more effective in open economies while fiscal policies are more effective in closed economies (Mundell: 1962; Fleming 1962). But there is no consensus on how the degree to which monetary policy influences exchange rate is related with openness.

Traditionally, economic theory predicts that monetary expansions lead to depreciation of the domestic currency, while monetary contractions have the opposite effects, leading to appreciation. ${ }^{1}$ These predictions have been supported by a voluminous empirical literature (Bryant and others: 1988; Taylor: 1993; Dornbusch and Giovannini: 1994). While monetary expansions are expected to result in depreciation of the national currency, the size of this depreciation may increase or decrease with the degree of openness of the economy. Karras (1999) argues that the strength of these exchange rate effects will depend on the degree of openness of an economy, but somehow this is theoretically ambiguous. ${ }^{2}$

Openness, as a concept, reveals itself in the international relations that concentrated more heavily in trade (goods and services) and finance sectors. Openness is shaped by liberalization of trade and finance, the nature of production and distribution strategies that become more international, and technological improvements which make the exchange of goods and services possible and eliminate the obstacles before the capital movements (Yi ğidim: 1999).

The theoretical intuition behind the difference between more open and less open economies in terms of the effectiveness of monetary policy can be explained as follows. On the demand side, an increase in money supply is expected to create similar effects in both economies, ${ }^{3}$ but it is likely to create quite different effects on the supply side. As pointed out by Karras (1999:75-76), because of the consequent

${ }^{1}$ Exchange rate can be defined in two ways. The first method defines it as the number of units of domestic currency one should pay for 1 unit of foreign currency. According to this definition, an increase in exchange rate indicates a depreciation, i.e. decrease in the value of domestic currency. The other alternative defines exchange rate as the number of units of foreign currency one should pay in order to purchase 1 unit of domestic currency. This study uses the first definition, which is adopted today by almost all countries, with United Kingdom as the only well known exception.

${ }^{2}$ See Karras (1999) for a formal mathematical derivation of this ambiguity. 
depreciation following a monetary expansion, wage demands increase by more in a highly open economy. This is because changes in the value of domestic currency will affect economic agents living in a highly open economy more seriously. The consequent more vigorous demand for wage increases will steepen aggregate supply curve. As a result, more of the monetary expansion will be reflected more on prices and less on output. The opposite will be true for the less open economy. ${ }^{4}$

In a broader context, exchange rate is regarded as one of the basic transmission mechanisms through which monetary expansion affects. ${ }^{5}$ This channel can be thought of a more critical factor in the context of openness. As Dennis (2001) puts it, on the financial side, exchange rates are key variables in small open economies. Exchange rate changes directly influence the prices of tradable goods. As domestic currency depreciates, ${ }^{6}$ the prices of imported consumer goods increase, raising the consumer price index. In addition, prices of imported intermediate goods go up, increasing firms' cost of production. Higher production costs tend to increase prices of consumer goods further as firms try to pass on higher costs to consumers. On the real side, a fall in the real value of domestic currency stimulates world demand for domestically produced goods, leading to an improvement in the trade balance.

The role of openness in affecting the monetary transmission mechanism can be explained as follows: In an open economy, exchange rate fluctuations in general leads to such expectations that the national currency will depreciate. This expectation itself will further stimulate demand for wage increases. Therefore, primary effect of a monetary expansion is expected to be reflected largely on prices, while its effects on output will be limited. This will lead to a larger contractionary effect on aggregate supply (Karras: 1999).

\footnotetext{
${ }^{3}$ Normally monetary expansion increases aggregate demand in two ways: first by decreasing interest rates, hence stimulating investment expenditures. Second, it increases demand through exchange rate depreciation (Berument and Doðan, 2003). Depreciation makes domestic goods cheaper and imported goods more expensive, thereby improving net exports, hence output. See also Romer (1993) for the theoretical reasoning behind the difference between more and less open economies in terms of inflationary effects.

${ }^{4}$ See Karras (1996) for some empirical tests supporting these relationships for output and prices.

${ }^{5}$ The other three channels are the interest rate channel, asset price channel, and credit channel (Mishkin, 1995).

${ }^{6}$ In this study, exchange rate is defined as how many units of domestic currency one has to pay for 1 unit of foreign currency. In this definition an increase in exchange rate indicates a decrease in the value of domestic currency.
} 
However, it is worth noting that theoretical and empirical literature so far has focused more on the effects of changes in money supply on the exchange rate, neglecting the role of openness. Karras (1999) further addressed the role of openness on the ability of monetary policy to affect the exchange rate. Using annual data for 1953-1990 period for a panel of 38 countries, he investigated the relationship between exchange rate, openness and monetary policy. His empirical results supported the theoretical predictions: the more open the economy, the smaller is the depreciation effects of a given change in the money supply.

Within this framework, the purpose of this article is to reinvestigate the relationship between exchange rate, openness, and monetary policy, and test Karras' findings under different specifications. In particular, the paper wants to a) check if Karras' findings can be confirmed for a different time period, as well as different country compositions, b) see if there is a meaningful differentiation between Developed (DCs) and Developing Countries (LDCs), c) see the performance of the model under different measures of openness and money. To this end, annual data for a panel of 41 countries $^{7}$ for the period of 1988-2000 are used to analyze the role of openness on the exchange rate effects of monetary policy. ${ }^{8}$

The rest of the paper is organized as follows: The following section introduces the model and the data. Section 3 presents and discusses the empirical results. Conclusions follow.

\section{The Model}

This study takes the model developed by Karras (1999) as the starting point. It has been modified in several ways, and the following model is estimated in order to evaluate the role of openness on the ability of monetary expansions to affect exchange rate. ${ }^{9}$

\footnotetext{
${ }^{7}$ The data included 42 countries, but USA is excluded from the analyses since the exchange rates are defined against the US dollar, hence the following 41 countries are included in the analysis: Germany, Australia, Austria, Belgium, Denmark, Finland, France, S. Korea, Netherlands, UK, Ireland, Spain, Sweden, Switzerland, Italy, Iceland, Japan, Canada, Hungary, Mexico, Norway, Poland, Portugal, Turkey, N. Zealand, Greece, Argentina, Brazil, El Salvador, Honduras, Panama, Paraguay, Uruguay, Venezuela, S. Africa, Egypt, Tunisia, Indonesia, India, Philippines, and Israel.

${ }^{8}$ Exchange rates for all countries are expressed in terms of the number of units of domestic currency against US dollar in order to enhance comparability.

${ }^{9}$ See Karras (1999) for a formal derivation on how openness is likely to influence the inflationary and output effects of monetary policy.
} 


$$
e_{j, t}=\gamma_{0}+\sum_{i=0}^{s}\left(\phi_{i}^{m} M_{j, t-1}+\phi_{i}^{O P N} O P N_{j, t} M_{j, t-1}\right)+u_{j, t}^{e}
$$

where, the dependent variable $e_{j, t}$ denotes the rate of change in the exchange rate of country $\mathrm{j}$ in period t, $M_{j, t}$ denotes the rate of change in M2Y of country $\mathrm{j}$ in period t. $O P N_{j, t} M_{j, t}$ is the interaction term and shows the effect of monetary policy on exchange rate depending on the degree of openness. ${ }^{10}$ Error terms are modeled as the fixed effects.

Broad definition of money, M2Y, is thought to be a better proxy for money supply changes for the purpose of this study. ${ }^{11}$ Data for the variables used are obtained from IMF's International Financial Statistics.

In economic literature, openness is defined by using various different measures. Among these are exports plus imports over GDP, imports over GDP, degree of interest rate differentiation or equalization between countries, degree of capital mobility, and trade orientation (Balassa and Bauwens: 1988). In empirical studies the first two criteria have been the most widely used openness measures (Romer, 1993; Rane, 1997; Edwards, 2001; Karras, 1999; Berument and Doğan, 2002; Akçay, 2000).

This study employs three of these measuresthe - first two and the last one mentioned - aboveto represent the degree of openness. OPN1, is defined as (imports+exports)/GDP. The second openness measure, OPN2, is based on imports only, excluding exports: (imports/GDP). The third measure, OPN3, is taken to be the proxy for trade orientation, and obtained by following Balassa and Bauwens (1988).

The latter, which has not been widely used so far, is used to define openness in a broader sense. The third openness measure is suggested by Balassa and Bauwens, and calculated as the residuals obtained by regressing logarithmic values of per capita imports on logarithmic values of per capita gross domestic product. These residuals that are taken to be proxies for trade orientation represent those variables - other than income and population - affecting imports. The residuals can be positive, negative or zero. Positive (negative) residuals indicate that the value of imports for a given country is above (below) the average. Accordingly, if imports

\footnotetext{
${ }^{10}$ The rate of change in exchange rates and the money supply are defined as follows, respectively: $\mathrm{e}_{\mathrm{j}, \mathrm{t}}=$ $\left(\mathrm{E}_{\mathrm{j}, \mathrm{t}}-\mathrm{E}_{\mathrm{j}, \mathrm{t}-1}\right) / \mathrm{E}_{\mathrm{j}, \mathrm{t}-1}$ and $\mathrm{M}_{\mathrm{j}, \mathrm{t}}=\left(\mathrm{M} 2 \mathrm{Y}_{\mathrm{j}, \mathrm{t}}-\mathrm{M} 2 \mathrm{Y}_{\mathrm{j}, \mathrm{t}-1}\right) / \mathrm{M} 2 \mathrm{Y}_{\mathrm{j}, \mathrm{t}-\mathrm{1}}$.

${ }^{11} \mathrm{M} 2 \mathrm{Y}=$ Money in circulation + Demand deposits + Time deposits + Deposits in foreign currency.
} 
are above (below) the average, this implies that protection in that country is relatively lower (higher). Therefore, when the residuals are sorted in a descending order, the country with the highest residual will be the most open one. We would like to see if this measure has a better explanatory power as opposed to the traditional ones.

We should stress the point that our model is not merely a replication of Karras (1999). It differs from his model both in terms of model specification and the estimation method. As far as the model specification is concerned, our equation is different in the following ways. Firstly, in addition to Karras' openness criteria exports plus imports over GDP, and imports over GDPwe used a third openness measure as explained above. Secondly, Karras used M1 to represent money stock whereas we used M2Y - M1 plus time deposits plus foreign currency denominated deposits. ${ }^{12}$ Thirdly, unlike Karras, there is no OIL term in our model. ${ }^{13}$

Estimation method is also different between the two models. Karras (1999) used Maximum Likelihood whereas we used Generalized Least Squares (GLS).

Moreover, the time period covered for the analysis is different: 1953-1990 vs. 1988-2000. There is not a very special reason for choosing this period. But the general reason is that many developing countries started to open their economies in the early 1980s, and there were a lot of initial transitional difficulties faced by these countries. We thought 1988 would be a good starting point to the new, economically more open era for many states. ${ }^{14}$ Lastly, country composition is not the same in the two studies.

Interaction between money growth rate (M) and openness measures are represented by $\mathrm{O} 1, \mathrm{O} 2$ and $\mathrm{O} 3$, and defined as follows.

$\mathrm{O} 1=(\mathrm{OPN} 1 * \mathrm{~m}), \mathrm{O} 2=(\mathrm{OPN} 2 * \mathrm{~m}), \mathrm{O} 3=(\mathrm{OPN} 3 * \mathrm{~m})$

\footnotetext{
${ }^{12}$ One reason to use M2Y is the fact that in developing countries a considerable part of deposits is accounted for by foreign currency deposits due partly to lack of confidence in the domestic currency.

${ }^{13}$ This is mainly because Karras took it as a proxy for supply shocks. This could be meaningful given that his study covers 1953-90 period, during which the world economy witnessed two major oil shocks during the 1970s. However this study covers 1988-2000 period. Since there were not comparable oil shocks during this period, we did not include an OIL term.

${ }^{14}$ In the meantime, our country, which can be viewed as a typical developing country in many respects, happened to define and use M2Y as a new and broadly defined money supply category in 1987, encouraging us to take 1988 as a suitable starting point. One can of course take many different periods and there is no end to asking why not this period, or that period. The critical thing is to choose a large enough sample to have explanatory power, and we think more than five hundred observations ( $13 \mathrm{x} 41$ $=533)$ is large enough for this matter.
} 
As far as the model specified in Equation (1) is concerned, the coefficient $\phi_{i}^{O P N}$ will show whether the effects of monetary policy on the exchange rate is strengthened with openness $\left(\phi_{i}^{O P N}>0\right)$, or weakened $\left(\phi_{i}^{O P N}<0\right)$. Theoretically, the sign of $\phi_{i}^{O P N}$ is uncertain ${ }^{15}$, hence it remains as an empirical question to investigate.

The above model is employed to estimate the parameter values using a fixed effect procedure. All countries are included in the panel data first. Then the countries are divided into two groups as "developed" and "developing" countries by making use of IMF's classification based on their GDP per capita, and the regression process is repeated. ${ }^{16}$

\section{Empirical Results}

As is known, in the analyses based on panel data, parameters can be estimated either by using fixed effects or random effects procedure. In a regression model given in the form of

$$
y_{i t}=\alpha_{i}+\beta^{\prime} x_{i t}+\varepsilon_{i t}
$$

the individual effect is $\alpha_{\mathrm{i}}$, which is taken to be constant over time $t$ and specific to the individual cross-sectional unit $i$. If $\alpha^{\prime}{ }_{\mathrm{i}} \mathrm{s}$ are taken to be the same across all units, then ordinary least squares provides consistent and efficient estimates of $\alpha$ and $\beta$. There are two basic frameworks used to generalize this model. The fixed effects approach takes $\alpha_{i}$ to be a group-specific constant term in the regression model. The random effects approach specifies that $\alpha_{i}$ is a group specific disturbance similar to $\varepsilon_{\mathrm{it}}$ except that for each group, there is but a single draw that enters the regression identically in each period. The fixed effects model is a reasonable approach when we can be confident that the difference between units can be viewed as parametric shifts of the regression function. This model might be viewed as applying only to the cross-sectional units in the study, not to additional

\footnotetext{
${ }^{15}$ See Karras (1999) for a formal derivation of this relationship, which shows the ambiguity of the sign of the openness coefficient.

${ }^{16}$ The following countries are included in the group of Developed Countries: USA, Germany, Australia, Austria, Belgium, Denmark, Finland, France, Netherlands, UK, Ireland, Spain, Sweden, Switzerland, Italy, Iceland, Japan, Canada, Norway, Portugal, N. Zealand, and Greece. The remaining countries listed in footnote 1 are included in the Developing Countries.
} 
ones outside the sample. For example, an intercountry comparison may well include the full set of countries for which it is reasonable to assume that the model is constant (Greene, 2000: 560, 567).

There are different views in the literature on which of these two procedures should be used. In this context, if factors (in this study, countries) are chosen arbitrarily, then fixed effects is preferred, while random effects would be more appropriate when factors are chosen randomly. Similarly, fixed effects is preferred if inferences obtained from the model are limited to the sample, whereas random effects is more appropriate if the inferences are to be generalized (Hsiao, 1986). Also Judge and others (1985) showed that the fixed effect estimator is more appropriate under more general assumptions. When "random effects procedure is used, fixed effects estimators are still consistent" (Jonston and Dinardo, 1997).

The main difference between the two procedures has to do with whether timetrends are correlated with independent variables. In this regard the fixed effects approach has one considerable virtue. There is no justification for treating the individual effects as uncorrelated with the other regressors, as is assumed in the random effects model (Greene, 2000: 576). Identification test developed by Hausman (1978) is suggested to decide if there exits such a correlation. Hausman test statistic asymptotically shows a $\chi^{2}$ distribution under the null hypothesis "random effects estimator is correct" with $\mathrm{K}$ degrees of freedom.

Given the fact that our sample units (countries) are not randomly selected from a very large population, and the risks associated with generalization of the results outside of the sample countries with considerable developmental and structural differences, we would expect that the fixed effects would be more appropriate framework for this study. Hausman test results (See Table 1 below) also indicated that the fixed effects procedure is the better choice. Therefore we used fixed effects procedure in all models in the study. Estimation results are reported in Table 1. Fixed effects are reported in the Appendix at the end of the paper.

As can be followed from Table 1, the coefficients $\mathrm{O} 1, \mathrm{O} 2$ and $\mathrm{O} 3$ in each model showing the interaction between openness and money supply are found to be negative and statistically significant. These results indicate that the higher the level of openness, the lower the effects of money supply changes on the exchange rate, which confirms Karras' results. This negative relationship implies that openness reduces the ability of monetary policy to affect exchange rates. As a result, in more open economies, depreciation effects of a given money supply shock will be lower.

The values for the coefficient $\mathrm{M}$, which represents money growth rate in the 
Table 1. Estimation Results

(Dependent variable: exchange rate growth, e; all countries: 1988-2000) ${ }^{\mathrm{a}}$

\begin{tabular}{|c|c|c|c|c|c|c|c|c|c|}
\hline Coefficients & $\mathrm{i}$ & ii & iii & iv & $\mathrm{v}$ & vi & vii & vii & ix \\
\hline $\mathrm{O} 1$ & $\begin{array}{c}-0.825 \\
(-145.33)\end{array}$ & & & $\begin{array}{c}-1.275 \\
(-17.02)\end{array}$ & & & $\begin{array}{c}-1.019 \\
(-10.25)\end{array}$ & & \\
\hline O1(-1) & $\begin{array}{l}0.013 \\
(4.25)\end{array}$ & & & $\begin{array}{l}0.009 \\
(2.59)\end{array}$ & & & $\begin{array}{l}0.085 \\
(1.83)\end{array}$ & & \\
\hline $\mathrm{O} 2$ & & $\begin{array}{c}-1.877 \\
(-169.97)\end{array}$ & & & $\begin{array}{c}-2.739 \\
(-20.71)\end{array}$ & & & $\begin{array}{l}-1.993 \\
(-9.42)\end{array}$ & \\
\hline $\mathrm{O} 2(-1)$ & & $\begin{array}{l}0.043 \\
(6.98)\end{array}$ & & & $\begin{array}{l}0.054 \\
(7.87)\end{array}$ & & & $\begin{array}{c}0.305 \\
(3.048)\end{array}$ & \\
\hline $\mathrm{O} 3$ & & & $\begin{array}{c}-0.411 \\
(-261.67)\end{array}$ & & & $\begin{array}{c}-0.623 \\
(-25.90)\end{array}$ & & & $\begin{array}{c}-0.595 \\
(-20.17)\end{array}$ \\
\hline $\mathrm{O} 3(-1)$ & & & $\begin{array}{c}0.022 \\
(21.06)\end{array}$ & & & $\begin{array}{c}0.024 \\
(19.00)\end{array}$ & & & $\begin{array}{c}0.007 \\
(0.44)^{\mathrm{b}}\end{array}$ \\
\hline M & & & & $\begin{array}{l}0.336 \\
(5.17)\end{array}$ & $\begin{array}{l}0.340 \\
(6.07)\end{array}$ & $\begin{array}{l}0.412 \\
(8.69)\end{array}$ & $\begin{array}{c}0.126 \\
(1.50)^{b}\end{array}$ & $\begin{array}{c}0.105 \\
(0.17)^{\mathrm{b}}\end{array}$ & $\begin{array}{l}0.364 \\
(6.14)\end{array}$ \\
\hline $\mathrm{M}(-1)$ & & & & & & & $\begin{array}{c}-0.056 \\
(-1.44)^{b}\end{array}$ & $\begin{array}{l}-0.102 \\
(-2.42)\end{array}$ & $\begin{array}{l}0.036 \\
(1.18)^{\mathrm{b}}\end{array}$ \\
\hline $\mathrm{R}^{2}$ & 0.61 & 0.65 & 0.76 & 0.61 & 0.65 & 0.74 & 0.62 & 0.67 & 0.75 \\
\hline $\bar{R}^{2}$ & 0.57 & 0.62 & 0.73 & 0.57 & 0.61 & 0.71 & 0.58 & 0.63 & 0.73 \\
\hline Hausman & 10.91 & 17.77 & 35.83 & 40.16 & 38.84 & 43.20 & 23.68 & 25.80 & 172.2 \\
\hline $\mathrm{n}$ & 451 & 451 & 451 & 451 & 451 & 451 & 451 & 451 & 451 \\
\hline
\end{tabular}

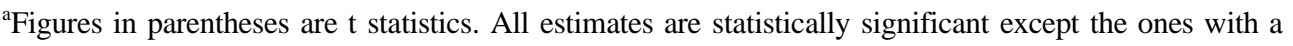
superscript $b$.

models, are estimated to be positive and significant in all model specifications. Consistent with theoretical expectations, greater money supply shocks lead to larger depreciation in domestic currency. Note that the third openness criterion gives better $\mathrm{R}^{2}$ values, which implies that trade orientation could also be used along with the other openness criteria. In order to check if it makes any difference between developed and developing countries, we repeated the regression after dividing the sample countries into two groups. Table 2 reports the estimation results when countries are divided as developed and developing categories.

Categorization of the countries is based on IMFs country classification. We use dummy variables to differentiate developed and developing countries, which are defined to be 1 for developed countries, and zero for developing countries. In this context, Dum-variables under each variable in each model (Table 2) represent the slope dummies for that particular variable. For each country slope dummy is defined as the product of dummy variable for that country and the corresponding explanatory variable. The sum of parameter and dummy values gives the value of the related parameters for developed countries. In this regard, for instance, in the 
Table 2. Estimation Results

(Dependent variable: exchange rate growth, e; Developed and Developing Countries are separated, 1988-2000) ${ }^{\mathrm{a}}$

\begin{tabular}{|c|c|c|c|c|c|c|c|c|c|}
\hline Coefficients & $\mathrm{i}$ & ii & iii & iv & $\mathrm{v}$ & vi & vii & viii & ix \\
\hline $\mathrm{O} 1$ & $\begin{array}{c}-0.642 \\
(-54.20)\end{array}$ & & & $\begin{array}{c}-2.067 \\
(-31.10)\end{array}$ & & & $\begin{array}{c}-1.693 \\
(-12.45)\end{array}$ & & \\
\hline DumO1 & $\begin{array}{c}-0,301 \\
(-22.76)\end{array}$ & & & $\begin{array}{c}2,044 \\
(32.18)\end{array}$ & & & $\begin{array}{c}1,670 \\
(13.04)\end{array}$ & & \\
\hline O1(-1) & $\begin{array}{c}0.049 \\
(-7.44)\end{array}$ & & & $\begin{array}{c}0.008 \\
(0.70)^{\mathrm{b}}\end{array}$ & & & $\begin{array}{c}0.073 \\
(0.96)^{b}\end{array}$ & & \\
\hline Dum O1(-1) & $\begin{array}{l}-0.044 \\
(-6.03)\end{array}$ & & & $\begin{array}{c}0.004 \\
(0.32)^{\mathrm{b}}\end{array}$ & & & $\begin{array}{c}-0.060 \\
(-0.79)^{\mathrm{b}}\end{array}$ & & \\
\hline $\mathrm{O} 2$ & & $\begin{array}{c}-1.660 \\
(-73.94)\end{array}$ & & & $\begin{array}{c}-3.854 \\
(-30.44)\end{array}$ & & & $\begin{array}{c}-3.973 \\
(-11.41)\end{array}$ & \\
\hline DumO2 & & $\begin{array}{c}-0.310 \\
(-11.96)\end{array}$ & & & $\begin{array}{c}3.839 \\
(31.88)\end{array}$ & & & $\begin{array}{c}3.156 \\
(12.10)\end{array}$ & \\
\hline $\mathrm{O} 2(-1)$ & & $\begin{array}{l}0.121 \\
(8.87)\end{array}$ & & & $\begin{array}{c}0.028 \\
(1.36)^{b}\end{array}$ & & & $\begin{array}{c}0.222 \\
(1.47)^{\mathrm{b}}\end{array}$ & \\
\hline DumO2(-1) & & $\begin{array}{l}-0.108 \\
(-7.19)\end{array}$ & & & $\begin{array}{c}-0.0006 \\
(-0.03)\end{array}$ & & & $\begin{array}{l}-0.167 \\
(-1.11)^{\mathrm{b}}\end{array}$ & \\
\hline $\mathrm{O} 3$ & & & $\begin{array}{c}-0.391 \\
(-80.58)\end{array}$ & & & $\begin{array}{c}-0.743 \\
(-63.69)\end{array}$ & & & $\begin{array}{c}-0.744 \\
(-47.62)\end{array}$ \\
\hline DumO3 & & & $\begin{array}{l}-0.020 \\
(-4.18)\end{array}$ & & & $\begin{array}{c}0.685 \\
(66.62)\end{array}$ & & & $\begin{array}{c}0.688 \\
(52.29)\end{array}$ \\
\hline $\mathrm{O} 3(-1)$ & & & $\begin{array}{l}0.032 \\
(9.48)\end{array}$ & & & $\begin{array}{l}0.031 \\
(8.18)\end{array}$ & & & $\begin{array}{c}-0.016 \\
(-1.07)^{\mathrm{b}}\end{array}$ \\
\hline DumO3(-1) & & & $\begin{array}{l}-0.025 \\
(-7.42)\end{array}$ & & & $\begin{array}{l}-0.033 \\
(-8.64)\end{array}$ & & & $\begin{array}{l}-0.034 \\
(-2.26)\end{array}$ \\
\hline M & & & & $\begin{array}{c}0.790 \\
(16.51)\end{array}$ & $\begin{array}{c}0.643 \\
(13.87)\end{array}$ & $\begin{array}{c}0.639 \\
(32.99)\end{array}$ & $\begin{array}{l}0.529 \\
(5.26)\end{array}$ & $\begin{array}{c}0.356 \\
(3.356)\end{array}$ & $\begin{array}{c}0.651 \\
(22.92)\end{array}$ \\
\hline DumM & & & & $\begin{array}{c}-1.674 \\
(-34.92)\end{array}$ & $\begin{array}{c}-1.537 \\
(-33.11)\end{array}$ & $\begin{array}{c}-1.693 \\
(-77.88)\end{array}$ & $\begin{array}{c}-1.413 \\
(-14.06)\end{array}$ & $\begin{array}{l}-1.249 \\
(-11.78)\end{array}$ & $\begin{array}{c}-1.708 \\
(-56.90)\end{array}$ \\
\hline $\mathrm{M}(-1)$ & & & & & & & $\begin{array}{c}-0.044 \\
(-0.76)^{b}\end{array}$ & $\begin{array}{l}-0.076 \\
(-1.26)^{b}\end{array}$ & $\begin{array}{l}0.104 \\
(3.53)\end{array}$ \\
\hline $\operatorname{DumM}(-1)$ & & & & & & & $\begin{array}{l}0.042 \\
(0.72)\end{array}$ & $\begin{array}{c}0.064 \\
(1.06)^{b}\end{array}$ & $\begin{array}{l}-0.010 \\
(-0.33)^{b}\end{array}$ \\
\hline $\mathrm{R}^{2}$ & 0.64 & 0.66 & 0.81 & 0.84 & 0.84 & 0.84 & 0.85 & 0.85 & 0.85 \\
\hline $\bar{R}^{2}$ & 0.60 & 0.62 & 0.79 & 0.82 & 0.83 & 0.82 & 0.83 & 0.84 & 0.82 \\
\hline Hausman & 62.62 & 68.19 & 63.92 & 102.5 & 88.11 & 99.22 & 169.7 & 217.5 & 2407 \\
\hline $\mathrm{n}$ & 451 & 451 & 451 & 451 & 451 & 451 & 451 & 451 & 451 \\
\hline
\end{tabular}

${ }^{\mathrm{a}}$ Figures in parentheses are $\mathrm{t}$ statistics. All estimates are statistically significant except the one with superscript $\mathrm{b}$.

first model in Table 2, the value of O1 (-0.642) shows the estimated value for developing countries, while the sum of this value with the value of DumO1 (slope dummy for O1: -0.301), gives the estimated value for developed countries (-0.642$0.301=-0.943)$. Same thing applies to all variables listed in Table 2.

As can be seen from Table 2, values of $\mathrm{O} 1, \mathrm{O} 2$ and $\mathrm{O} 3$ in the models for both 
developing and developed countries are estimated to be negative and significant. Notice that for developed countries, coefficients showing the interaction between openness and money supply are found to be close to zero. These results indicate that, in terms of both individual ( $\mathrm{t}$ and $\mathrm{t}-1$ ) and combined effects for all models, generally the higher the openness, the lower the effect of monetary expansion on exchange rate for both developing and developed countries. However, the strength of this effect seems to be stronger for the developing countries.

For developing countries the parameter values for money growth (M) in the models are estimated to be all positive and significant. This implies that monetary expansions lead to depreciation of domestic currency for developing countries. The reason behind this finding may be explained as follows. Monetary expansions lead to a fall in interest rates. This is not surprising, because, in an open economy with liberalized capital account, this stimulates capital flight, which causes domestic currency to depreciate (Dornbusch and Fischer, 1994). The surprising result, on the other hand, comes with the estimation of the same parameter for developed countries.

The estimated values for money parameter for these countries are negative and significant. This seemingly unexpected result implies that monetary expansions for developed countries would lead to appreciation, and not depreciation, of the domestic currency. In an effort to see if this result is related with exchange rate regime rather than the level of development, several different scenarios were tried. ${ }^{17}$

First of all, the model is estimated by using only developing countries with flexible exchange rate regimes. ${ }^{18}$ The results for money coefficients are found to be consistent with the aforementioned results found for all countries, as well as for developing countries without altering the values for openness terms qualitatively. Same results are obtained when the regressions were repeated for a more limited sample of developing countries after taking out some countries with pegged regimes in the first half (1988-1992) of the sample period. Different lag structures did not alter these results. ${ }^{19}$ In short, regression results with different specifications consistently indicated two main findings: Openness reduces the ability of monetary

\footnotetext{
${ }^{17}$ We would like to thank an anonymous referee for suggesting these checks.

${ }^{18}$ IMFs International Financial Statistics is used as a reference to categorize the countries with respect to exchange rate regimes.

${ }^{19}$ The model could not be estimated for developing countries with pegged exchange rate regime for the whole period because of the lack of enough observations, since only two countries (Argentina and Panama) implemented fixed exchange rate regime during this period. In addition to these two, the following developing countries also used pegged regimes during 1988-1992: El Salvador, Honduras, Israel, Hungary, and Poland.
} 
policy to affect exchange rate, and monetary expansions result in depreciation of domestic currency for developing countries. This negative relationship between money and exchange rate does not seem to hold for developed countries.

As far as the main purpose of this study is concerned, the results confirm the previous empirical findings of Karras (1999) in terms of the role of openness in affecting the ability of monetary policy on changes in exchange rates. The empirical results of this paper, however, do not seem to support the expectation that increases in money supply depreciate the local currency for developed countries. ${ }^{20}$

We do not have definite answers as to why currency seems to appreciate in developed countries as money expands. Among the possible reasons one might think of are differences in expectations of individuals, structural characteristics of economies, speed of the transmission mechanism, and the degree of antiinflationary sensitivity of the monetary authority in developed vs. developing countries. For instance, in a developed country a monetary authority might increase interest rates as a reaction to monetary expansion in an effort to prevent inflation from rising, which in return might attract foreign funds into the country, leading the local currency to appreciate. In any case, further investigation of the possible causes of this difference between developed versus developing countries would be a promising subject for future research.

\section{Conclusion}

This paper examines whether the effects of monetary policy on the exchange rates depend on the degree of openness of an economy. Theoretically, it can be shown that the effect of openness on the ability of money to influence the exchange rate is ambiguous. This relationship is investigated by using panel data of 41 developing and developed countries for 1988-2000 period.

The results obtained from the analyses indicate the following conclusions: 1) Openness reduces the ability of monetary policy to affect exchange rate, defined as units of domestic currency to purchase one unit of US dollar. Regardless of whether countries are developed or developing, whether they adopt fixed or flexible exchange rate regimes, there is a negative relationship between the degree of openness and the effect of money growth on exchange rate. 2) Monetary expansions lead to depreciation of domestic currency for developing countries. For

\footnotetext{
${ }^{20}$ Regressions were repeated with and without EU members- and Iceland-as pegged countries, qualitatively same results were obtained.
} 
the developing countries as a whole with no separation with respect to exchange rate regimes for the period 1988-2000, as well as for developing countries with flexible regimes for the same period indicated that money growth leads to depreciation. 3) Monetary expansions do not seem to depreciate domestic currency for the developed countries with or without flexible exchange rate regimes. There found to be a negative relationship between money growth and exchange rate for the developed countries.

In sum, the empirical findings of this study indicate that the influence of monetary policy on exchange rate decreases as an economy becomes more open. In addition, the findings regarding whether monetary expansions depreciate or appreciate the domestic currency shows a significant difference between developed and developing countries. In developing countries local currency depreciates as money supply grows, while it goes the other way around for developed countries, and it seems to be robust across pegged and flexible exchange rate regimes.

Conclusions 1 and 2 are in conformity with theoretical expectations as well as a number of previous empirical studies. But conclusion 3 is a seemingly unexpected result, which implies that the local currency appears to appreciate as money supply grows for developed countries. Explaining the possible reasons behind this unexpected finding deserves to give more thought on it; hence it would be a promising area of research in the future.

Received 20 June 2003, Accepted 22 March 2004

\section{References}

Akçay, Selçuk. (2000), "Yolsuzluk, Ekonomik Özgürlükler ve Demokrasi”, (Corruption, Economic Freedoms and Democracy), Muğla Üniversitesi Sosyal Bilimler Enstitüsü Dergisi, (Muğla University Journal of Social Sciences Institute) Fall 2000, 1(1): 115.

Balassa, B. and L. Bauwens (1988), Changing Trade Patterns in Manufactured Goods, An Econometric Investigation, Amsterdam: North Holland.

Berument, Hakan (2002), "Döviz Kuru Hareketleri ve Enflasyon Dinamiği: Türkiye Örne ği," (Exchange Rate Movements and Inflation Dynamics: Turkish Experience), Bilkent University Discussion Papers, No: 02-02, March 2002, pp. 1-14.

Berument, H. and B. Doğan (2003) "Openness and the Effectiveness of Monetary Policy: Empirical Evidence from Turkey," Applied Economics Letters, 10: 217-221.

Berument, H. and M. Paşaoğullari "Effects of Real Exchange Rate on Output and Inflation: Evidence from Turkey," Developing Economies, (forthcoming). 
Bryant, R., D. Henderson, G. Holtham, P. Hooper, S. Symansky (1988), Empirical Macroeconomics for Interdependent Economies, Washington, DC: Brookings Institution.

Dennis, R. (2001) "Monetary Policy and Exchange Rates in Small Open Economies," FRBSF Economic Letter, 16(May):1-4.

Dornbusch, R., A. Giovannini (1990), "Monetary Policy in the Open Economy," in B.M. Friedman and F.H. Hahn (eds.) Handbook of Monetary Economics, New York: North Holland.

Dornbusch, R., S. Fischer (1994), Macroeconomics, Sixth Edition, Singapore: McGraw-Hill.

Edwards, Sebastian (2001), "Dollarization: Myths and Realities," National Bureau of Economic Research, March.

Fleming, J.M. (1962), "Domestic Financial Policies Under Fixed and Under Floating Exchange Rates," IMF Staff Papers, Vol. 9: 369-376.

Greene, W. H. (2000), Econometric Analysis, Fourth Edition, Upper Saddle River, NJ: Prentice Hall.

Hausman, J. (1978), “Specification Tests in Econometrics,” Econometrica, Vol. 46: 1251-1271.

Hsiao, C. (1986), Analysis of Panel Data, Cambridge: Cambridge Univ. Press.

Johnston, J. and J. Dinardo (1997), Econometric Methods, Fourth ed., New York: McGraw-Hill.

Judge, G.G, W.E. Griffiths, R.C. Hill, H. Lutkepohl, T.C. Lee (1985), The Theory and Practice of Econometrics, New York: John Wiley.

Kamin, S.B. and J.H. Rogers (2000) "Output and Real Exchange Rate in Developing Countries: An Application to Mexico," Journal of Developing Economics, 62: 85-109.

Karras, Georgios (1999), "Monetary Policy and the Exchange Rate: The Role of Openness", International Economic Journal, 13(2): 75-88.

Karras, Georgios (1996), "Are the Effects of Monetary Policy Asymmetric? Evidence from a Panel of European Countries," Oxford Bulletin of Economics and Statistics, May: 267-278.

Mishkin, Frederic S. (1995) "Symposium on the Monetary Transmission Mechanism," Journal of Economic Perspectives, 9(4): 3-10.

Mundell, R.A. (1962), "The Appropriate Use of Monetary and Fiscal Policy for Internal and External Stability, IMF Staff Papers, Vol. 9, March: 70-77.

Obstfeld, M. ve K. Rogoff (1996), Foundations of International Macroeconomics, Cambridge: MIT Press.

Rane, Philip R. (1997), "Inflation in Open Economies," Journal of International Economics, Vol. 42: 327-347.

Romer, David (1993), "Openness and Inflation: Theory and Evidence," Quarterly Journal of Economics, Vol. 108: 869-903.

Taylor, John B. (1993), Macroeconomic Policy in a World Economy, New York: Norton.

Yiğidim, Arslan (1999), "A Systematic Approach to Understand the Reasons Behind the Tendencies of Developing Countries to Participate in the Globalization Process," I ktisat I şletme ve Finans, Supplement to the 157th Issue, April: 48-59. 


\section{Appendix}

\section{Fixed Effects Obtained from the Models in Table 1}

\begin{tabular}{|c|c|c|c|c|c|c|c|c|c|}
\hline Countries & Model I & Model II & Model III & Model IV & Model V & Model VI & Model VII & Model VIII & Model IX \\
\hline Germany & 0.049411 & 0.051647 & 0.063210 & 0.044373 & 0.045097 & 0.061216 & 0.049393 & 0.054790 & 0.060690 \\
\hline Argentina & 327113 & 0.324073 & .320305 & .201565 & 0.189700 & 0.153735 & \begin{tabular}{|l|}
0.299300 \\
\end{tabular} & 0.353392 & 0.160027 \\
\hline Austria & 053744 & 0.056600 & 0.066368 & .044624 & 0.047068 & 0.060010 & \begin{tabular}{|l|}
0.053090 \\
\end{tabular} & 0.060989 & 0.059522 \\
\hline Australia & 049996 & 0.052768 & 0.058920 & 0.050083 & 0.051618 & 0.060534 & 0.050806 & 0.054087 & 0.060077 \\
\hline Belgium & 173341 & 0.189524 & 0.161709 & .215849 & 0.223575 & 0.184193 & 0.187586 & 0.187649 & 0.181758 \\
\hline Brazil & 713537 & 5.714990 & 5.733546 & 5.677097 & 5.676808 & 5.696884 & \begin{tabular}{|l|}
5.707016 \\
\end{tabular} & 5.726329 & 5.697100 \\
\hline Denmark & 0.037219 & 0.037895 & 0.043728 & 0.035953 & 0.035420 & 0.043684 & 0.037508 & 0.039272 & 0.043386 \\
\hline El Salvador & 122935 & 0.147454 & 0.161945 & 0.111774 & 0.141659 & 0.161150 & 0.122934 & 0.152713 & 0.159852 \\
\hline Indonesia & 241948 & 0.245958 & 0.264093 & 0.230827 & 0.232267 & 0.256991 & 0.241774 & 0.252814 & 0.256030 \\
\hline Philippines & 0.158226 & 0.173890 & 0.183571 & 0.156792 & 0.172596 & 0.185995 & \begin{tabular}{|l|}
0.160344 \\
\end{tabular} & 0.177714 & 0.184672 \\
\hline Finland & 049309 & 0.049258 & 0.048333 & 0.049646 & 0.049722 & 0.048734 & \begin{tabular}{|l|}
0.049567 \\
\end{tabular} & 0.049600 & 0.048629 \\
\hline France & 714 & 0.035029 & 338 & 0.029102 & 0.029881 & 501 & 3498 & 0.037536 & 169 \\
\hline South Africa & 0.114351 & 0.114488 & 0.118528 & 0.110917 & 0.110352 & 0.115881 & \begin{tabular}{|l|}
0.114308 \\
\end{tabular} & 0.116745 & 0.115581 \\
\hline South Korea & 0.188115 & 0.190426 & 0.213633 & 0.187542 & 0.181217 & 0.213016 & \begin{tabular}{|l|}
0.191554 \\
\end{tabular} & 0.197265 & 398 \\
\hline India & 83 & 0.116 & 689 & 440 & 0641 & 522 & 1416 & 0.121478 & 927 \\
\hline Netherlands & 0.053561 & 0.055215 & 0.033053 & 0.057448 & 0.056903 & 0.022490 & 0.054839 & 0.055182 & 0.022164 \\
\hline Honduras & 333633 & 0.352073 & 0.336650 & 0.345523 & 0.364974 & 1816 & \begin{tabular}{|l|}
0.339123 \\
\end{tabular} & 0.353638 & 0.34 \\
\hline UK & 40 & 70 & 145 & 442 & 866 & 759 & 382 & & 320 \\
\hline Ireland & 0.250927 & 0.258818 & 0.190680 & 0.292007 & 0.288009 & 0.185330 & 0.266825 & 0.260970 & 0.184416 \\
\hline Spain & 0.064381 & 0.066721 & 0.088058 & 0.058544 & 0.060720 & 0.092541 & \begin{tabular}{|l|}
0.064031 \\
\end{tabular} & 0.069599 & 0.09 \\
\hline Israel & & & 615 & 602 & & & 3472 & 0.159652 & \\
\hline Sweden & 0.046006 & 0.045707 & 0.046606 & 0.045927 & 0.045418 & 0.047055 & 0.046024 & 0.045874 & 0.047066 \\
\hline Switzerland & 0.028689 & 0.030135 & 0.036522 & 0.026671 & 0.026884 & 0.035965 & \begin{tabular}{|l|}
0.028780 \\
\end{tabular} & 0.031661 & 0.035615 \\
\hline Italy & 0.051284 & 284 & 0.051632 & 0.051107 & 0.051227 & 2150 & 0.051646 & 0.052073 & 133 \\
\hline Iceland & 0.071467 & 0.076650 & 0.071646 & 0.070374 & 0.074099 & 141 & 0.072639 & 0.079244 & 0.0 \\
\hline Japanese & -0.00708 & -0.00706 & 0.027139 & -0.02126 & -0.02220 & 0.027275 & -0.00944 & -0.00226 & 0.026721 \\
\hline Canada & 0.05 & 0.0 & 813 & 350 & 3444 & 780 & 4595 & 0.058764 & 928 \\
\hline Hungary & 0.197198 & 0.203337 & 0.194294 & 0.199147 & 0.203574 & \begin{tabular}{|l|}
0.188446 \\
\end{tabular} & \begin{tabular}{|l|}
0.199469 \\
\end{tabular} & 0.205956 & 8124 \\
\hline Mexico & 0.197105 & 0.205710 & 0.254429 & 0.176809 & 0.183536 & 0.254274 & \begin{tabular}{|l|l|}
0.197213 \\
\end{tabular} & 0.218354 & 0.252702 \\
\hline Egypt & 0.154144 & 0.154014 & 0.160668 & 8732 & 0.147593 & 5857 & 0.152806 & 0.155540 & 5868 \\
\hline Norway & 0.048295 & 0.049495 & 0.053855 & 0.048153 & 0.048092 & 4254 & \begin{tabular}{|l|}
0.048889 \\
\end{tabular} & 0.050702 & 932 \\
\hline Panama & 0.260798 & 0.290830 & 0.198643 & 0.346993 & 0.365995 & 0.233295 & 0.288525 & 0.285088 & 0.229709 \\
\hline Paraguay & 0.183275 & 0.205786 & 0.213492 & 0.184478 & 0.209585 & 0.219677 & \begin{tabular}{|l|l|}
0.186033 \\
\end{tabular} & 0.208425 & 0.218187 \\
\hline Poland & 0.276129 & 0.283851 & 0.316871 & 0.255530 & 0.258553 & 1483 & 0.273004 & 0.290883 & 120 \\
\hline Portugal & 0.079696 & 0.092764 & 0.101856 & 0.076100 & 0.091198 & 0.103987 & \begin{tabular}{|l|l|}
0.080369 \\
\end{tabular} & 0.095213 & 0.103155 \\
\hline Tunisia & 0.086720 & 0.094390 & 0.093742 & 0.091402 & 0.098207 & 0.097131 & 0.089043 & 0.095147 & 0.096465 \\
\hline Turkey & 0.751898 & 0.762467 & 0.778926 & 0.736298 & 0.747338 & 0.768574 & 0.750831 & 0.769872 & 0.767673 \\
\hline Uruguay & 0.336566 & 0.340032 & 0.356583 & 0.321239 & 0.322978 & 0.344297 & \begin{tabular}{|l|l|}
0.334789 \\
\end{tabular} & 0.346515 & 0.343806 \\
\hline Venezuela & 0.347280 & 0.341605 & 0.357789 & 0.338490 & 0.326308 & 0.346458 & \begin{tabular}{|l|}
0.345758 \\
\end{tabular} & 0.344099 & 0.346763 \\
\hline Greece & 0.139158 & 0.160852 & 0.109165 & 0.156645 & 0.182771 & 0.106215 & 0.143706 & 0.157190 & 0.105899 \\
\hline N. Zealand & 0.052335 & 0.053932 & 0.062477 & 0.048815 & 0.049151 & 0.061116 & 0.052427 & 0.056271 & 0.060688 \\
\hline
\end{tabular}




\section{Fixed Effects Obtained from the Models in Table 2}

\begin{tabular}{|c|c|c|c|c|c|c|c|c|c|}
\hline Coun & Todel I & Iodel II & Model III & Model IV & Model V & Model VI & Model VII & Moc & Model \\
\hline & & & 35 & 558 & 663 & & & & \\
\hline 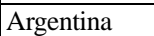 & & & 97 & & & & & & \\
\hline Austria & 56319 & 058013 & 0.068169 & 083574 & 0.083632 & 0.085586 & 0.083732 & 0.084128 & .083497 \\
\hline Austr & 53934 & 054778 & \begin{tabular}{|l|}
0.060869 \\
\end{tabular} & .058752 & 0.058637 & 0.058024 & \begin{tabular}{|l|}
0.058828 \\
\end{tabular} & \begin{tabular}{|l|}
0.058726 \\
\end{tabular} & 0.058462 \\
\hline Belg & 51 & 548 & 65 & 494 & 59 & 22 & 562 & & 72 \\
\hline Brazil & & 84 & 5. & 576 & & & & & \\
\hline Denmark & 39575 & 039009 & 0.044887 & 0.045930 & 0.046023 & 0.045796 & \begin{tabular}{|l|}
0.045987 \\
\end{tabular} & 0.02 & 0.045726 \\
\hline El Sal & 93 & 133796 & \begin{tabular}{|l|}
0.154504 \\
\end{tabular} & 102751 & 0.144790 & 0.159812 & 111 & 906 & 518 \\
\hline Indon & 7773 & 237648 & \begin{tabular}{|l|}
0.258577 \\
\end{tabular} & 048 & 0.224968 & 072 & 0.2 & 516 & 145 \\
\hline Philir & & & 0.1 & & 24 & 27 & 81 & & 13 \\
\hline Finland & 9070 & 549279 & \begin{tabular}{|l|}
0.048754 \\
\end{tabular} & 047802 & 0.047752 & 7791 & 821 & 811 & 7674 \\
\hline France & 429 & 035949 & 0.042567 & 0.049726 & 0.049791 & 579 & 319 & 073 & 5564 \\
\hline South 1 & 20 & 112944 & 0.11 & 930 & 0.107528 & 090 & \begin{tabular}{|l|}
0.1 \\
\end{tabular} & 718 & 313 \\
\hline South & 97 & 47 & 0.2 & 82 & & & & & \\
\hline India & 89 & 14447 & \begin{tabular}{|l|}
0.148046 \\
\end{tabular} & 53 & 634 & 13 & 227 & 167 & 7773 \\
\hline Netherland & 58242 & 057599 & 0.033661 & 0.053968 & 0.053887 & 0.061055 & \begin{tabular}{|l|}
0.054019 \\
\end{tabular} & 817 & 0.057463 \\
\hline Honduras & 21 & 337210 & 0.3 & 476 & 657 & 0.344128 & 31 & 558 & 337 \\
\hline UK & 30 & 552375 & 0.07 & 23 & 00 & 0.0 & 0.0 & 04 & 78 \\
\hline Ireland & 111 & 269569 & \begin{tabular}{|l|}
0.194408 \\
\end{tabular} & 698 & 251 & 365 & 791 & 839 & 433 \\
\hline Spain & 5244 & 067795 & \begin{tabular}{|l|}
0.090436 \\
\end{tabular} & .083947 & 0.083924 & 0.08 & \begin{tabular}{|l|}
0.084057 \\
\end{tabular} & 248 & \begin{tabular}{|l|}
0.081939 \\
\end{tabular} \\
\hline Israel & 31 & 0.143220 & 0.12 & 0.14 & 148 & 583 & 0.1 & 0.1 & 200 \\
\hline Sweder & 108 & 045866 & 0.0 & 378 & 385 & 264 & 0.0 & 421 & 583 \\
\hline Switze & 21 & 80 & 0.0 & 0.02 & 561 & 0.0 & 0.0 & 0.0 & 681 \\
\hline Italy & 90 & 99 & 0.05 & 53 & 219 & 47 & 0.0 & 326 & 269 \\
\hline Iceland & 77482 & 0.079719 & 0.073723 & 0.0 & 863 & 0.0 & 0.0 & 0.0 & 0.0 \\
\hline Japane & 77 & 48 & 0.0 & 70 & 3664 & 379 & 0.0 & 246 & 353 \\
\hline Canada & 03 & 47 & 0.0 & 0.06 & 894 & 0.0 & 0.0 & 103 & 695 \\
\hline ungar & & 56 & & 0.20 & 736 & 985 & 0.2 & & 325 \\
\hline Mexico & 027 & 0.194049 & \begin{tabular}{|l|}
0.244209 \\
\end{tabular} & 0.154968 & 0.170626 & 0.252104 & \begin{tabular}{|l|}
0.173311 \\
\end{tabular} & \begin{tabular}{|l|}
0.198690 \\
\end{tabular} & 0.248108 \\
\hline Egypt & 051 & 0.153169 & \begin{tabular}{|l|}
0.160013 \\
\end{tabular} & 0.142443 & 0.142475 & 0.153402 & \begin{tabular}{|l|}
0.146667 \\
\end{tabular} & 232 & 0.151910 \\
\hline Norway & 27 & 050855 & 0.0 & 0.05 & 170 & 985 & 197 & 265 & 052 \\
\hline Panama & 91766 & 0.245275 & \begin{tabular}{|l|}
0.184508 \\
\end{tabular} & 0.489814 & 0.461129 & 0.251183 & \begin{tabular}{|l|}
0.403687 \\
\end{tabular} & \begin{tabular}{|l|}
0.387946 \\
\end{tabular} & \begin{tabular}{|l|}
0.254870 \\
\end{tabular} \\
\hline Paraguay & 162391 & 0.189931 & 0.205865 & 0.194287 & 0.222754 & 0.222533 & 0.190412 & 0.220393 & 0.221376 \\
\hline Poland & 311 & 0.270240 & \begin{tabular}{|l|}
0.308600 \\
\end{tabular} & 227 & 0.244403 & 518 & \begin{tabular}{|l|}
0.250948 \\
\end{tabular} & \begin{tabular}{|l|}
0.271037 \\
\end{tabular} & \begin{tabular}{|l|}
0.287006 \\
\end{tabular} \\
\hline Portugal & 56 & 0.096447 & 0.104960 & 0.10 & 2416 & 728 & 3630 & 5560 & 2197 \\
\hline Tunisia & 074425 & 0.085590 & \begin{tabular}{|l|}
0.089671 \\
\end{tabular} & 0.102204 & 0.106921 & 0.098420 & \begin{tabular}{|l|}
0.096289 \\
\end{tabular} & \begin{tabular}{|l|}
0.103544 \\
\end{tabular} & 0.098066 \\
\hline Turkey & 740263 & 0.753759 & 0.773545 & 0.719617 & 0.739119 & 0.762160 & 0.732886 & 0.757353 & 0.756370 \\
\hline $\mathrm{cog}_{10}$ & 57 & 0.3 & 0.3 & 0.3 & 80 & 78 & 871 & 0.3 & \begin{tabular}{|l|}
0.331537 \\
\end{tabular} \\
\hline Venezuela & 696 & 0.337101 & 0.3 & 0.330826 & 557 & 0.34 & \begin{tabular}{|l|}
0.336763 \\
\end{tabular} & 620 & \begin{tabular}{|l|}
0.337739 \\
\end{tabular} \\
\hline Greece & 3192 & 0.166370 & 0.110682 & 0.11 & 375 & 0.119246 & \begin{tabular}{|l|l|}
0.113825 \\
\end{tabular} & 0.110669 & \begin{tabular}{|l|}
0.118479 \\
\end{tabular} \\
\hline Zealand & 055406 & 0.055481 & 0.064216 & 0.068585 & 0.068658 & 0.068836 & \begin{tabular}{|l|}
0.068684 \\
\end{tabular} & \begin{tabular}{|l|}
0.068896 \\
\end{tabular} & 0.068350 \\
\hline
\end{tabular}

